$\mathrm{JH}$ lus Quia Iustum is licensed under a Creative Commons Attribution 4.0 Intemational License. Which Pemils unrestricted use, distrubution, and reproduction in any medium, provided the original work is properly cited

\title{
Pertentangan Antara Diskresi Kebijakan Dengan Penyalahgunaan Wewenang Dalam Tindak Pidana Korupsi
}

\author{
Nur Kumalaningdyah \\ Fakultas Hukum Universitas Islam Indoensia \\ Jln. Tamansiswa No. 158 Yogyakarta \\ nurningdyah@gmail.com
}

Received: 28 September 2018; Accepted: 20 Mei 2019; Published: 17 Februari 2020

DOI: 10.20885 /iustum.vol26.iss3.art3

\begin{abstract}
This study aims to determine the relationship between policy discretion and abuse of authority by public officials that lead to corruption. This is a normative legal research that was conducted through literature study that is relevant to the problem at hand. The results of the study concluded that in accordance with the unlawful nature (wederrechtelijkheid) as a limitation of the authority of public officials in carrying out policies (discretion) without relying on the legislation; discretion may be considered an abuse of authority if it defies Law Number 30 of 2014 on Government Administration.
\end{abstract}

Keywords: Discretion; policy; abuse; authority; corruption

\section{Abstrak}

Penelitian ini ditujukan untuk mengetahui hubungan diskresi kebijakan dan penyalahgunaan wewenang oleh pejabat publik yang mengarah pada tindak pidana korupsi. Penelitian ini merupakan penelitian hukum normatif yang dilakukan dengan studi kepustakaan terkait dengan permasalahan yang diteliti. Hasil penelitian menyimpulkan bahwa sejalan dengan sifat melawan hukum (wederrechtelijkheid) sebagai pembatas kewenangan pejabat publik dalam melakukan kebijakan (diskresi) tanpa bergantung pada peraturan perundangan; diskresi dapat dianggap penyalahgunaan kewenangan jika mengingkari Undang-Undang Nomor 30 Tahun 2014 tentang Administrasi Pemerintahan.

Kata kunci: Diskresi; kebijakan; penyalahgunaan; wewenang; korupsi 


\section{Pendahuluan}

Ada kalanya banyak situasi dalam menjalankan fungsi pemerintahan, salah satunya, ketika pejabat pemerintahan dihadapkan pada situasi yang kewenangan untuk bertindaknya tidak diatur melalui peraturan perundang-undangan. Tetapi, ada keperluan yang mendesak bagi pemerintah untuk bertindak guna mencapai tujuan tertentu sehingga diharuskan untuk memutuskan tindakan itu dalam rangka memenuhi kebutuhan hukum masyarakat.

Freies Ermessen (Diskkresionare) ${ }^{1}$ merupakan salah satu sarana yang memberi ruang gerak bagi pejabat pemerintahan atau badan-badan administrasi negara untuk melakukan tindakan tanpa harus terikat sepenuhnya pada undang-undang. Pemerintah dalam menjalankan aktivitasnya berdasarkan freies Ermessen tidak boleh bertindak sewenang-wenang, kendati ada peluang terjadinya benturan kepentingan antara pemerintah dengan warga negara.

Menyadari adanya potensi benturan kepentingan antara pemerintah dan warga negara, pemerintah mengeluarkan Undang-Undang Nomor 30 Tahun 2014 tentang Administrasi Pemerintahan (UU Administrasi Pemerintahan) sebagai solusi untuk permasalahan tersebut sekaligus untuk memberikan perlindungan hukum baik kepada pejabat publik maupun masyarakat. Dalam UU Administrasi Pemerintahan, terdapat "Diskresi" yang harus dipahami oleh pejabat publik dalam pengambilan tindakan bilamana dilakukan.

Diskresi atau kebijakan sesuai dengan UU Administrasi Pemerintahan merupakan Keputusan dan/atau Tindakan yang ditetapkan dan/atau dilakukan oleh pejabat pemerintahan untuk mengatasi persoalan konkret yang dihadapi dalam penyelenggaraan pemerintahan, melancarkan penyelenggaraan pemerintahan, dan memberikan kepastian hukum ketika peraturan perundangundangan yang memberikan pilihan tidak memberikan aturan, tidak lengkap, tidak jelas, dan/atau karena adanya stagnasi pemerintahan. Tujuannya adalah untuk mengisi kekosongan hukum dan memajukan kemanfaatan dan kepentingan umum. $^{2}$

1 Minarno, Nur Basuki, Penyalahgunaan Wewenang dan Tindak Pidana Korupsi dalam Pengelolaan Kenangan Daerah, Cetakan ke-2, Penerbit Laksbang Mediatama, Palangkaraya, 2009.

2 Mustamu, Julista, "Diskresi dan Tanggungjawab Administrasi Pemerintahan", Jurnal Sasi, Vol. 17 No. 2, April-Juni 2011, hlm. 1-9. 
Diskresi atau kebijakan hanya dapat dilakukan oleh pejabat pemerintahan yang berwenang. Pejabat pemerintahan dalam pengambilan diskresi diharapkan tetap selaras atau sesuai dengan tujuan akhir yang sudah ditetapkan dan harus ada conditio sine quo non yang mendasari diskresi yang dilakukan. Conditio sine qua non itu setidaknya adalah ketiadaan dan/atau ketidakjelasan suatu peraturan yang akan digunakan untuk menyelesaikan masalah yang timbul dalam keadaan kegentingan dan memaksa.

Diskresi pada tataran pelaksanaan haruslah sesuai dengan aturan main peraturan perundang-undangan. ${ }^{3}$ Ukuran diskresi menurut asas-asas umum pemerintahan yang baik dan berdasar pada ketentuan peraturan perundangundangan, di antaranya: adanya kejujuran (fair-play), kecermatan (zorgvuldigheid), kemurnian dalam tujuan (zuiverheid van oogmerk), keseimbangan (evenwichtigheid), kepastian hukum (rechts zekerheid). ${ }^{4}$ Secara spesifik, ruang lingkup diskresi sesuai dengan Pasal 23 UU Administrasi Pemerintahan, adalah:

a. berdasarkan ketentuan peraturan perundang-undangan yang memberikan suatu pilihan Keputusan dan / atau Tindakan;

b. karena peraturan perundang-undangan tidak memberikan aturan;

c. karena peraturan perundang-undangan tidak lengkap atau tidak jelas; dan

d. karena adanya stagnasi pemerintahan guna kepentingan yang lebih luas.

Pasal 24 UU Administrasi Pemerintahan juga mensyaratkan agar diskresi:

a. sesuai dengan tujuan diskresi sebagaimana dimaksud dalam Pasal 22 ayat (2);

b. tidak bertentangan dengan ketentuan peraturan perundang-undangan;

c. sesuai dengan Asas asas Umum Pemerintahan yang Baik (AUPB);

d. berdasarkan alasan-alasan yang objektif;

e. tidak menimbulkan konflik kepentingan; dan

f. dilakukan dengan iktikad baik.

Asas-asas Umum Pemerintahan yang Baik (AUPB) merupakan konsep yang terbuka dan berkembang. Konsep ini disesuaikan dengan ruang dan waktu di mana AUPB itu dilaksanakan. Menurut Philipus M. Hadjon,5 AUPB harus

3 Sumeleh, Elisa J.B., "Implementasi Kewenangan Diskresi dalam Perspektif Asas-asas Umum Pemerintahan yang Baik (AUPB) Berdasarkan Undang-Undang No.30 Tahun 2014 tentang Administrasi Pemerintahan", Lex Administratum, Vol. 5 No. 9, November 2017, hlm. 130-137.

4 Ibid.

5 Minarno, Loc. Cit. 
dipandang sebagai norma hukum tidak tertulis yang senantiasa harus ditaati oleh pemerintah.

Asas-asas Umum Penyelenggaraan Negara dalam Pasal 3 Undang-Undang Nomor 28 Tahun 1999 tentang Penyelenggaraan Negara yang Bersih dan Bebas dari Korupsi, Kolusi, dan Nepotisme (UU Penyelenggaraan Negara yang Bersih dan Bebas dari KKN), meliputi

a. asas kepastian hukum yang mengutamakan landasan peraturan perundangundangan, kepatuhan, dan keadilan dalam setiap kebijakan penyelenggaraan negara;

b. asas tertib penyelenggara negara yang menjadi landasan keteraturan, keserasian, keseimbangan dalam pengabdian penyelenggara negara;

c. asas proporsionalitas yang mengutamakan keseimbangan antara hak dan kewajiban penyelenggara negara;

d. asas profesionalitas yang mengutamakan keahlian berlandaskan keahlian, kode etik, dan ketentuan peraturan perundang-undangan yang berlaku;

e. asas akuntabilitas yang menentukan bahwa setiap kegiatan dan hasil akhir dari kegiatan penyelenggaraan negara harus dapat dipertanggungawabkan kepada masyarakat atau rakyat sebagai pemegang kedaulatan tertinggi sesuai dengan ketentuan peraturan yang berlaku;

f. asas keterbukaan yang membuka diri terhadap hak masyarakat untuk memperoleh informasi yang benar, jujur, dan tidak diskriminatif tentang penyelenggaraan negara dengan tetap memperhatikan perlindungan atas hak asasi pribadi, golongan, dan rahasia negara.

g. asas kepentingan umum yang mendahulukan kesejahteraan umum dengan cara aspiratif, akomodatif, dan kolektif.

Jika Pasal 3 UU Penyelenggaraan Negara yang Bersih dan Bebas dari KKN sudah dilaksanakan, maka dapat disimpulkan bahwa diskresi tidak dapat dikelompokkan sebagai penyalahgunaan kewenangan yang mengarah pada tindak pidana korupsi apabila tindakan diskresi oleh pejabat pemerintahan berpedoman pada AUPB dan UU Administrasi Pemerintahan, yang telah memberi pengertian, batasan, serta prosedur penggunaan diskresi atau dengan kata lain telah menjadi payung hukum bagi pejabat pemerintahaan untuk menggunakan diskresi.

Adapun yang dimaksud kewenangan yang tercantum dalam UndangUndang Nomor 31 Tahun 1999 jo. Undang-Undang Nomor 20 Tahun 2001 tentang Tindak Pidana Korupsi (UU Tipikor) menurut Wiyono ${ }^{6}$ adalah serangkaian hak

${ }^{6}$ Susilo, Agus Budi, "Makna dan Kriteria Diskresi Keputusan dan/atau Tindakan Pejabat Publik dalam Mewujudkan Tata Pemerintahan yang Baik", Jurnal Hukum dan Peradilan, Vol. 4 No. 1, Maret 2015, hlm. 133-152. 
yang melekat pada jabatan atau kedudukan dari pelaku tindak pidana korupsi untuk mengambil tindakan yang diperlukan agar tugas pekerjaannya dapat dilaksanakan dengan baik. Adapun wewenang menurut Pasal 1 angka 5 UU Administrasi Pemerintahan adalah hak yang dimiliki oleh badan dan/atau pejabat pemerintahan atau penyelenggara negara lainnya untuk mengambil keputusan dan/atau tindakan dalam penyelenggaraan pemerintahan. Sedangkan kewenangan menurut Pasal 1 angka 6 UU Adminsitrasi Pemerintahan adalah kekuasaan badan dan/atau pejabat pemerintahan atau penyelenggara negara lainnya untuk bertindak dalam ranah hukum publik.

Penyalahgunaan kewenangan dalam Hukum Administrasi berdasarkan yurisprudensi di Perancis, menurut Jean Rivero dan Waline ${ }^{7}$, dapat diartikan dalam tiga wujud, yaitu:

a. penyalahgunaan kewenangan untuk melakukan tindakan-tindakan yang tidak sesuai dengan kepentingan umum atau untuk kepentingan pribadi, kelompok atau golongan;

b. penyalahgunaan dalam arti bahwa tindakan pejabat tersebut adalah benar ditujukan untuk kepentingan umum, tetapi menyimpang dari tujuan apa kewenangan tersebut diberikan oleh Undang-Undang atau peraturanperaturan lain;

c. penyalahgunaan kewenangan dalam arti menyalahgunakan prosedur yang seharusnya dipergunakan untuk mencapai tujuan tertentu, tetapi telah menggunakan prosedur lain agar terlaksana.

Berangkat dari berbagai pandangan tentang penyalahgunaan kewenangan dalam tindak pidana korupsi, khususnya yang dipandang dari cara melakukan perbuatannya, dengan demikian terdapat tiga bentuk spesifik dari penyalahgunaan wewenang, yaitu: pertama, melampaui kewenangan yang ada; kedua, bertindak diluar kewenangan yang ada; dan ketiga, menggunakan kewenangan yang ada untuk tujuan lain dari yang seharusnya. ${ }^{8}$

Konsep penyalahgunaan wewenang, khususnya dalam aspek hukum pidana, diadopsi dari konsep penyalahgunaan wewenang dalam hukum administrasi negara yang pada prinsipnya memberikan makna bahwa penyalahgunaan kewenangan merupakan penggunaan kewenangan yang tidak sesuai dengan

\footnotetext{
${ }^{7}$ Ridwan, Diskeresi \& Tanggung Jawab Pemerintah, Penerbit FH UII Press, Yogyakarta, 2014.

${ }^{8}$ Minarno, Loc. Cit.
} 
tujuan dari diberikannya kewenangan itu. Pada tataran teoretis, tujuan dari diskresi adalah untuk kepentingan umum atau kemaslahatan masyarakat. Dengan demikian, apabila diskresi ditujukan selain dari kepentingan umum atau kemaslahatan masyarakat, maka tindakan diskresi tersebut secara sederhana dapat dikelompokkan sebagai penyalahgunaan wewenang. ${ }^{9}$

Kategorisasi diskresi sebagai penyalahgunaan wewenang dapat mendasar pada Pasal 3 UU Tipikor, yaitu penyalahgunaan wewenang dengan menggunakan jabatan dan kedudukan serta peluang yang ada, adanya kekosongan atau kesempatan dari ketentuan tertentu, dengan cara atau metode kerja yang berkaitan dengan jabatan atau kedudukannya itu. Perbuatan diskresi yang demikian masuk dalam kategori perbuatan melawan hukum dan masuk dalam tindak pidana korupsi.

Pengkelompokan diskresi sebagai tindak pidana korupsi dan penyalahgunaan wewenang yang terkait dengannya menjadi objek penelitian yang menarik untuk dibahas. Diskresi yang pada hakikatnya merupakan wewenang dari pejabat pemerintahan untuk mengeluarkan keputusan atau melakukan tindakan atas inisiatifnya sendiri tanpa bergantung pada peraturan perundangundangan yang berlaku sering kali dianggap sebagai penyalahgunaan wewenang oleh aparat penegak hukum. Ketiadaan peraturan yang jelas mengenai prosedur, penggunaan, serta batasan-batasan dari diskresi adalah pangkal dari masalahnya. ${ }^{10}$

\section{Rumusan Masalah}

Sehubungan dengan uraian di atas, dapat dirumuskan masalah, bagaimanakah pertentangan antara diskresi kebijakan dengan penyalahgunaan wewenang oleh badan/pejabat pemerintah yang mengarah pada tindak pidana korupsi?

\section{Tujuan Penelitian}

Adapun tujuan makalah ini adalah untuk mengetahui pertentangan antara diskresi kebijakan dengan penyalahgunaan wewenang dalam pengambilan

${ }_{9}$ Afdiningsih, Fuji Lara Sakti, H.A. Sihabudin, dan Puspita Asri Praceka, "Framing Pemberitaan Diskresi Ahok untuk Reklamasi Jakarta pada Majalah Tempo, Kajian Jurnalisme, Vol. 1 No. 1, 2017, hlm. 58-69.

${ }_{10}$ Hutuley, In, Alwi, dan Hasniati, "Diskresi dalam Implementasi Kebijakan Alokasi Dana Desa di Kecamatan Leihitu Kabupaten Maluku Tengah”, STIA Abdul Azis Kataloka Ambon, 2013, hlm. 1-13 
keputusan dan/atau tindakan oleh badan dan/atau pejabat pemerintah yang mengarah pada tindak pidana korupsi.

\section{Metode Penelitian}

Penelitian ini merupakan penelitian hukum normatif yang dilakukan dengan studi kepustakaan. Jenis data yang digunakan adalah data sekunder yang diperoleh dari bahan-bahan pustaka yang relevan, yaitu mencakup bahan hukum primer, bahan hukum sekunder, dan bahan hukum tersier. Setelah memperoleh data, data itu diolah dan dianalisis sehingga diperoleh gambaran yang jelas dan konkrit terhadap objek yang dibahas secara kualitatif dan disajikan secara deskriptif sesuai dengan permasalahan penelitian ini. ${ }^{11}$

\section{Hasil Penelitian dan Pembahasan}

Tindak pidana korupsi dalam konteks timbulnya kerugian keuangan negara, baik berupa potensi kerugian keuangan negara maupun kerugian keuangan negara secara nyata, tidak serta-merta dapat dijadikan sebagai tolok ukur untuk mengelompokkan diskresi sebagai tindak pidana korupsi. Hal ini disebabkan karena tindakan diskresi yang merupakan inisiatif sendiri dari pejabat pemerintahan dan tidak berdasarkan pada peraturan perundang-undangan. Kendati tindakan tersebut sangat berpotensi untuk merugikan keuangan negara. ${ }^{12}$

Ada atau tidaknya niat jahat (mens rea) pada diri pelaku pada saat mengeluarkan diskresi karenanya harus diperhatikan untuk menentukan diskresi sebagai tindak pidana korupsi. Di samping itu, tindakan diskresi sebagai tindak pidana korupsi juga mensyaratkan adanya individu-individu atau kelompokkelompok tertentu bahkan suatu korporasi yang diuntungkan. ${ }^{13}$ Dengan demikian, tindakan diskresi yang dikelompokkan sebagai tindak pidana korupsi tidak semata-mata merugikan keuangan negara dan niat dari pelakunya.

\footnotetext{
11 Jaya, Ikmal, “Implementasi Kebijakan Diskresi pada Sistem Pelayanan Publik di Kota Tegal”, Jurnal Pembaharuan Hukum Vol. 1 No. 2, Mei-Agustus 2014, hlm. 1-9

${ }^{12}$ Nurudin, Agus, "Diskresi Yudisial: Antara Keadilan dan Pencitraan”, Jurnal Masalab-masalah Hukum, Jilid 45 No. 1 Januari 2016, hlm. 18-24

${ }^{13}$ Wijaya, Ika Hadi, Istislam, dan Moh. Fadli, "Keabsahan Diskresi dalam Penyelesaian Sisa Pekerjaan yang Bukan Disebabkan Force Majeure”, Program Magister Ilmu Hukum, Universitas Brawijaya, 2015, hlm. 1-26
} 


\section{Penyalahgunaan Wewenang oleh Pejabat Publik}

Konsep penyalahguaan wewenang dalam hukum pidana pada dasarnya telah tercermin dari adanya sifat melawan hukum yang merupakan unsur mutlak dari suatu tindak pidana. Karenanya, sifat melawan hukum secara tidak langsung menjadi tolok ukur untuk membatasi diskresi dalam aspek hukum pidana. Ajaran sifat melawan hukum sebagai tolok ukur untuk membatasi diskresi memiliki karakteristik yang lebih spesifik dari pada ajaran perbuatan melawan hukum. Hal ini disebabkan karena ajaran tentang sifat melawan hukum telah secara spesifik digunakan dalam hukum pidana. Sedangkan ajaran perbuatan melawan hukum tidak hanya ada dalam hukum pidana, tetapi juga hukum administrasi negara, sehingga bersifat lebih umum. ${ }^{14}$

Hukum pidana tidak menentukan pengertian "menyalahgunakan kewenangan". Kendati demikian, hukum pidana mempunyai otonomi untuk menggunakan pengertian "menyalahgunakan kewenangan" dari hukum administrasi. Hal ini dalam hukum pdana dikaitkan dengan tugas Hakim untuk melakukan penemuan hukum. Sebagai contoh, perbuatan terdakwa yang telah menggunakan dan menyalahgunakan diskresi dalam jabatannya dapat dilihat dalam halaman 18 Yurisprudensi Putusan MA No.1537 K/Pid/2003 tertanggal 27 September 2007 dalam perkara Drs. H. Sudaryanto. Perbuatan Sudaryanto yang terbukti telah melakukan "pencairan kredit tanpa agunan yang lengkap", menurut Mahkamah Agung, adalah merupakan "kewenangan" dalam arti menyalahgunakan prosedur yang seharusnya dipergunakan untuk mencapai tujuan tertentu in casu untuk mencairkan kredit.

Selain itu pada Putusan MA No. 2349 K/PID.SUS/2012 tanggal 21 Agustus 2013 dalam perkara a.n. Yossep M. Ridwan bin M. Asy'ari selaku konsultan pengawas;

a. ... unsur menyalahgunakan kewenangan ini, akan dikaitkan dengan asas kepatutan, kecermatan dalam Hukum Adminitrasi negara yang dikenal dengan Asas-asas Umum Pemerintahan yang baik (AUPB) (Algemene Beginselen van Behoorlijk Bestuur).

b. ... melakukan penghalusan hukum (recht vervijning) dengan cara mengambil alih pengertian menyalahgunakan kewenangan sebagaimana disebutkan

${ }^{14}$ Susilo, Agus Budi, "Makna dan Kriteria Diskresi Keputusan dan/atau Tindakan Pejabat Publik dalam Mewujudkan Tata Pemerintahan yang Baik", Jurnal Hukum dan Peradilan, Vol. 4 No. 1, Maret 2015, hlm. 133-152 
dalam Pasal 52 ayat (2) huruf b Undang-Undang Nomor 5 Tahun 1986 tentang Peradilan Tata Usaha Negara, yaitu menggunakan wewenangnya untuk tujuan lain dari maksud diberikannya wewenang tersebut.

c. ... dengan cara menilai apakah tindakan Terdakwa telah menyimpang dari maksud dan tujuan pemberian wewenang tersebut, apabila menyimpang perbuatan tersebut dikelompokan sebagai penyalahgunaan wewenang (Detournement de Pouvoir).

Contoh lain dari Putusan MA No. 2349 K/PID.SUS/2012 tanggal 21 Agustus

2013 dalam perkara a.n. Yossep M. Ridwan bin M. Asy'ari selaku konsultan pengawas, adalah sebagai berikut;

Dari tugas dan tanggung jawabnya selaku Konsultan Pengawas maka terdakwa Yossep M. Ridwan bin M. Asy'ari tidak melaksanakan tugas dan fungsinya selaku pengawas sehingga dianggap sebagai bentuk tidak menggunakan kewenangan yang ada padanya selaku Konsultan Pengawas; Menimbang, bahwa dengan pertimbangan sebagaimana tersebut di atas, maka perbuatan terdakwa tersebut telah menguntungkan diri sendiri atau orang lain atau suatu korporasi dengan menyalahgunakan kewenangan, kesempatan atau sarana yang ada padanya karena jabatan atau kedudukan.

Putusan MA No. 1144 K/Pid/2006 tanggal 13 September 2007 dalam perkara

a.n. Edward Cornellis William Neloe selaku Direktur Utama PT. Bank Mandiri (Persero) Tbk;

... para Terdakwa menyetujui suatu pinjaman yang disebut "dana talangan" atau "bridging loan" sesuatu formula yang tidak dikenal dan tidak mempunyai dasar hukum. Perbuatan ini sangat nyata sebagai suatu yang tidak semata menyalahgunakan wewenang, yaitu menggunakan wewenang tidak sesuai tujuan, tetapi sebagai perbuatan di luar hukum (out of law), karena itu bersifat sewenang-wenang (willekeurig atau arbitrary). Terdakwa meletakkan diri di atas hukum, bukan tunduk pada hukum.

Putusan Nomor: 674 K/PID/2005 tanggal 15 September 2005 dalam perkara

a.n. Terdakwa Muaz Munziri, S.E.,MSM;

Terdakwa sebagai Ketua DPRD seharusnya tidak dapat melakukan rangkaian perbuatan yang semestinya termasuk lingkup tugas eksekutif. Terdakwa telah mengambil kebijaksanaan yang disebut dalam pertimbangan putusan Hakim Pertama "sebagai freies Ermessen" yang berada di luar lingkup tugas dan wewenangnya.Dengan dalih freies Ermessen tersebut Terdakwa telah meminta dana kepada Bupati dan diberikan walaupun bukan dari mata anggaran yang diperuntukkan dalam kegiatan seperti itu. Dengan demikian dari aspek hukum pidana, maka apa yang dilakukan oleh Terdakwa dengan dibungkus 
sebagai ("kebijaksanaan/freies Ermessen) adalah merupakan "penyalahgunaan wewenang" abuse of power dan bersifat melawan hukum.

Putusan MA. No. 2547 K/PID.SUS/2011 tanggal 07 Maret 2012 pada perkara Walikota Bekasi Mochtar Mohamad;

Sebagai Walikota ternyata Terdakwa bertindak sewenang-wenang menurut kehendaknya sendiri (naar willekeur handelen) antara lain dengan cara memberi hadiah dan atau menjanjikan sesuatu kepada Pejabat (Suharto Tim Pemeriksa BPK-RI) yang menangani proses penentuan WTP terhadap Laporan Keuangan Pemda; Disamping itu juga dalam hal penganugerahan Adipura untuk Pemda Kota Bekasi; Hal yang sama juga dilakukan oleh Terdakwa dalam rangka pengesahan RAPBD Kota Bekasi.

Hakikat kewenangan menurut Pasal 1 angka 6 UU Administrasi Pemerintahan adalah kekuasaan badan dan/atau pejabat pemerintahan atau penyelenggara negara lainnya untuk bertindak dalam aspek hukum publik. Pada umumnya, pengertian penyalahgunaan kewenangan, kesempatan, atau sarana yang ada didasarkan pada adanya suatu jabatan atau kedudukan tertentu. ${ }^{15}$ Adapun kata "kedudukan" dalam perumusan ketentuan tentang tindak pidana korupsi, berarti: ${ }^{16}$

a. Pegawai Negeri sebagai pelaku Tindak Pidana Korupsi yang tidak memangku suatu jabatan tertentu, baik jabatan struktural maupun jabatan fungsional; dan

b. Pelaku Tindak Pidana Korupsi yang bukan pegawai negeri atau perseorangan swasta yang mempunyai fungsi dalam suatu korporasi.

Adapun kata "kedudukan" dalam perumusan ketentuan tentang tindak pidana korupsi berarti: ${ }^{17}$

a. perbuatan seseorang dapat dikategorikan dalam unsur-unsur tindak pidana korupsi dengan cara menyalahgunakan kewenangan, kesempatan, atau sarana yang ada karena jabatan atau kedudukan, adalah Pegawai Negeri.

b. pelaku tindak pidana korupsi yang bukan pegawai negeri atau perseorangan swasta hanya dapat melakukan tindak pidana korupsi dengan cara menyalahgunakan kesempatan atau sarana yang ada karena kedudukan saja.

Sehubungan dengan putusan-putusan tersebut di atas, ada beberapa kelebihan dalam penggunaan diskresi oleh badan atau pejabat publik. Pertama,

${ }^{15}$ Maka dari itu, pejabat yang mempunyai kedudukanlah yang mempunyai kekuasaan

16 Minarno, Loc. Cit.

${ }^{17}$ Minarno, Loc. Cit. 
kebijakan pemerintah yang bersifat darurat terkait hajat hidup orang banyak dapat segera diputuskan atau diberlakukan oleh pemerintah, meskipun masih dapat dibantah secara yuridis atau bahkan terjadi kekosongan pengaturan hukum sama sekali. Kedua, badan atau pejabat publik tidak terjebak pada formalisme hukum, dalam arti tidak ada kekosongan pengaturan hukum bagi setiap kebijakan publik sepanjang berkaitan dengan kepentingan umum atau masyarakat luas. Ketiga, sifat dan roda pemerintahan menjadi luwes, sehingga sektor pelayanan publik makin hidup dan pembangunan bagi peningkatan kesejahteraan rakyat menjadi tidak statis seiring dengan dinamika masyarakat dan perkembangan zaman. ${ }^{18}$

Problematika mengenai diskresi yang seringkali dihubungkan dengan tindakan penyalahgunaan wewenang maupun tindakan sewenang-wenang tidak serta merta diakibatkan oleh pejabat publik yang menggunakan diskresi melampaui batasannya. Namun, diskresi justru seringkali mendapat justifikasi sebagai tindak pidana berupa penyalahgunaan wewenang yang mengarah kepada tindak pidana korupsi karena pemahaman dari praktisi hukum sangat positivistik sehingga memandang diskresi sebagai tindakan tanpa dasar hukum karena tidak bersandar pada peraturan perundang-undangan. Keadaan tersebut membawa akibat pada timbulnya ketidakpastian hukum pada bidang tindakan administrasi negara yang pada gilirannya menganggu kinerja pejabat publik karena takut tindakan diskresinya akan dianggap sebagai tindak pidana. ${ }^{19}$

Berdasarkan UU Administrasi Pemerintahan, penyalahgunaan kewenangan dapat terjadi pada wewenang terikat maupun wewenang jenis diskresi. Tolok ukur penyalahgunaan kewenangan pada jenis wewenang terikat adalah asas legalitas, sedangkan jenis diskresi digunakan tolok ukur AUPB. ${ }^{20}$

Penerapan AUPB sebagai tolak ukur untuk membatasi diskresi dapat diterima dalam aspek hukum administrasi negara. Namun, apabila berbicara mengenai konteks hukum pidana yang sering kali menjustifikasi diskresi sebagai

\footnotetext{
${ }^{18}$ Indarti, Erlyn, "Penegakan Hukum dan Diskresi: Suatu Telaah Paradigmatik", Makalah pada Training Rule of Law Sebagai Basis Penegakan Hukum dan Keadilan, Jakarta, Oktober-November 2015, hlm. 1-15.

${ }_{19}$ Prakoso, Abintoro, "Vage Normen sebagai Sumber Hukum Diskresi yang belum Diterapkan oleh Polisi Penyidik Anak”, Jurnal Hukum, No.2 Vol.17 April 2010, hlm. 249-270.

20 Ridwan, "Diskresi (Freies Ermessen) oleh Pejabat publik: Rambu Hukum, Alat Ukur Keabsahan, dan Kecermatan dalam Penggunaanya", Fakultas Hukum Universitas Sriwijaya, Vol. 16 No. 3, Desember 2009, hlm. 439-450.
} 
tindakan penyalahgunaan wewenang yang mengarah kepada tindak pidana korupsi, maka AUPB sangat jarang ditemukan dalam pertimbangan putusan hakim sebagai alasan untuk melegalisasi tindakan diskresi pejabat publik. Hal tersebut disebabkan karena AUPB merupakan asas hukum yang sifatnya abstrak dan berbentuk norma hukum yang tidak tertulis. Sekalipun AUPB telah dimuat dalam peraturan perundang-undangan, ketentuan tersebut masih dipandang terlalu luas dan abstrak untuk dijadikan sebagai bahan pertimbangan untuk melegalisasi tindakan diskresi jika diperhadapkan dengan hukum pidana. ${ }^{21}$

Setelah diundangkannya UU Administrasi Pemerintahan, pejabat publik setidaknya dapat lepas dari keraguan untuk menggunakan diskresi karena adanya justifikasi diskresi sebagai tindakan penyalahgunaan kewenangan yang mengarah pada tindak pidana korupsi. Dengan telah dirumuskannya karakteristik dan ruang lingkup diskresi secara yuridis, diskresi yang dilakukan pejabat publik memiliki ukuran yang jelas sekaligus meminimalisasi perbedaan pandangan mengenai sah atau tidaknya suatu diskresi, serta menjawab pertanyaan apakah suatu tindakan diskresi dapat dikualifikasikan sebagai tindak pidana korupsi atau tidak.

Diskresi dalam UU Administrasi Pemerintahan adalah keputusan dan/atau tindakan yang ditetapkan dan/atau dilakukan oleh pejabat publik untuk mengatasi persoalan konkret yang dihadapi dalam penyelenggaraan pemerintahan dalam hal peraturan perundang-undangan yang memberikan pilihan, tidak memberikan aturan, tidak lengkap atau tidak jelas, dan/atau adanya stagnasi pemerintahan.

Pengertian yang diberikan Pasal 23 Undang-Undang Administrasi Pemerintahan Nomor 30 Tahun 2014, jelaslah bahwa seorang pejabat publik boleh menggunakan diskresi apabila peraturan perundang-undangan memberikan pilihan, tidak memberikan aturan, tidak lengkap atau tidak jelas dan/atau adanya stagnasi pemerintahan. Di luar kriteria yang diberikan UU Administrasi Pemerintahan, tentu keputusan atau tindakan yang diambil seorang pejabat publik tidak termasuk dalam lingkup yang disebut dengan diskresi. 


\section{Diskresi Kebijakan sebagai Pilihan}

UU Administrasi Pemerintahan memberikan penafsiran yang konkrit, berdasarkan pengertian diskresi itu sendiri, mengenai kapan suatu diskresi dapat digunakan. Berdasarkan penjelasan Pasal 23 huruf a UU Administrasi Pemerintahan, dijelaskan bahwa pilihan keputusan dan/atau tindakan pejabat publik dicirikan dengan kata dapat, boleh, atau diberikan kewenangan, berhak, seharusnya, diharapkan, dan kata-kata lain yang sejenis dalam ketentuan peraturan perundang-undangan. Sedangkan yang dimaksud pilihan keputusan dan/atau tindakan adalah respon atau sikap pejabat publik dalam melaksanakan atau tidak melaksanakan administrasi pemerintahan sesuai dengan ketentuan peraturan perundang-undangan. Sebagai bentuk kewenangan yang diberikan oleh hukum, tindakan diskresi pemerintah adalah tindakan yang absah (rechtmatig). Meskipun, adakalanya tindakan tersebut menyimpang atau tidak sesuai dengan undang-undang atau legislasi. Dalam kondisi demikian, diskresi tidak serta merta dapat dikualifikasikan sebagai tindakan melawan hukum. Diskresi baru dapat dipandang sebagai tindakan melawan hukum manakala dapat dibuktikan bahwa tindakan diskresi tersebut merupakan praktek dari penyalahgunaan kewenangan.

\section{Diskresi dalam Hal Peraturan Perundang-undangan Tidak Memberikan Aturan}

Berdasarkan UU Administrasi Pemerintahan, terkait dengan penggunaan diskresi karena peraturan perundang-undangan tidak memberikan aturan dengan penjelasan, yang dimaksud dengan "peraturan perundang-undangan tidak memberikan aturan" adalah ketiadaan atau kekosongan hukum yang mengatur penyelenggaraan pemerintahan dalam suatu kondisi tertentu atau di luar kebiasaan. Berdasarkan pengertian penyalahgunaan kewenangan dalam aspek hukum administrasi negara yang kemudian diadopsi ke dalam aspek hukum pidana, tolak ukur utama dalam menentukan apakah tindakan diskresi pejabat publik dapat dikualifikasikan sebagai penyalahgunaan kewenangan adalah bertumpu pada tujuan dari dilakukannya diskresi. Dalam rumusan diskresi yang negatif, maka diskresi akan dianggap sebagai tindakan penyalahgunaan kewenangan jika tindakan pemerintah tidak sesuai dengan tujuan dari suatu kewenangan tertentu. Suatu diskresi akan dianggap sebagai tindakan 
penyalahgunaan kewenangan apabila tujuan dari diskresi tersebut tidak benar. Sementara jika diskresi dirumuskan secara positif, maka suatu tindakan pemerintah akan dianggap tidak sesuai dengan asas spesialitas atau asas tujuan. ${ }^{22}$

\section{Diskresi dalam Hal Peraturan Perundang-undangan Tidak Lengkap atau Tidak Jelas}

Diskresi pejabat publik atas alasan peraturan peraturan perundangundangan tidak lengkap atau tidak jelas dapat dipraktikkan apabila terdapat peraturan perundang-undangan masih membutuhkan penjelasan lebih lanjut, peraturan yang tumpang tindih, dan peraturan yang membutuhkan peraturan pelaksanaan, tetapi belum dibuat. Oleh karena itu, diskresi kewenangan diberikan untuk membuat kebijakan. Tujuannya adalah agar pejabat publik tidak menolak hal tertentu dengan alasan tidak ada undang undang yang mengaturnya, walaupun tindakan pemerintah seharusnya berdasarkan undang-undang. Sebab, dalam urusan pemerintah, tidak pada setiap urusan ada undang undangnya sehingga diberikanlah kewenangan diskresi kepada pejabat publik tersebut. ${ }^{23}$

\section{Diskresi Karena Adanya Stagnasi Pemerintahan}

Berdasarkan penjelasan UU Administrasi Pemerintahan terhadap kriteria tentang adanya stagnasi pemerintahan yang terkait dengan kepentingan yang lebih luas, yang dimaksud dengan "kepentingan yang lebih luas" adalah kepentingan yang menyangkut hajat hidup orang banyak, penyelamatan kemanusiaan dan keutuhan negara, antara lain bencana alam, wabah penyakit, konflik sosial, kerusuhan, pertahanan dan kesatuan bangsa. ${ }^{24}$

Pejabat publik dari beberapa keadaan memungkinkannya menggunakan diskresi dengan memperhatikan kriteria diskresinya. Diskresi atas keadaan adanya peraturan perundang-undangan memberikan pillihan, tidak lengkap atau tidak jelas, dan tidak memberikan aturan mengenai suatu hal kongkrit, jelas memerlukan suatu analisis, penelitian, dan penelusuran peraturan perundang-undangan,

\footnotetext{
22 Supeno, Hadi, “Korupsi di Daerah: Kesaksian, Pengalaman, dan Pengakuan”, Penerbit Total Media Yogyakarta, 2009, hlm. 27-32. 90.

${ }^{23}$ Ridwan, "Diskresi \& Tanggung Jawab Pemerintah", Penerbit FH UII Press, Yogyakarta, 2014, hlm. 86-

${ }^{24}$ Irawan, Benny, "Diskresi sebagai Tindak Pidana Korupsi: Kajian Kriminologi dan Hukum terhadap Fenomena Pejabat Otoritas”, Mimbar, Vol. 27 No. 2, Desember 2011, hlm. 143-149.
} 
sehingga ketika suatu diskresi digunakan, misalnya karena peraturan perundangundangan tidak lengkap, padahal sebenarnya lengkap, tetapi dinyatakan tidak lengkap karena tidak melakukan penelusuran hukum. Begitu juga dengan diskresi karena perundang-undangan tidak memberikan aturan. Hal tersebut tidak boleh disimpulkan sepintas, melainkan harus melalui suatu penelitian, penelusuran, dan analisis hukum. Apabila kriteria dari suatu keadaan yang membolehkan seorang pejabat publik sudah terpenuhi, maka barulah diskresi boleh dilakukan dan itupun melalui prosedur yang telah ditentukan dalam UU Administrasi Pemerintahan.

Kebanyakan fakta yang terjadi pada saat ini yang berkaitan dengan fungsi pengawasan yang dilakukan oleh aparat pengawasan internal dan eksternal serta para penegak hukum yang sangat positivistik, menyebabkan penyelenggaraan kewenangaan pejabat publik berupa implimentasi dari freies ermessen atau diskresi berujung pada tuntutan hukum secara pidana. Keadaan ini membawa akibat pada timbulnya ketidakpastian hukum di bidang tindakan administrasi negara, yang pada gilirannya mengganggu kinerja pejabat publik karena menimbulkan pembunuhan karakter terhadap praktek penyelenggaraan pemerintahan yang sehat. Oleh sebab itu, dibutuhkan ketegasan dan kejelasan serta perlindungan terhadap pejabat publik dalam melaksanakan tindakan hukum administrasi dalam kerangka diskresi atau freies ermessen agar pejabat publik dapat menjalankan fungsinya dan kepentingan masyarakat dapat tercapai.

Arti penting dari perlunya analisis dan pendalaman pejabat publik dalam memutuskan untuk menggunakan diskresi tidak terlepas dari beberapa hal penting terkait dengan penggunaan diskresi, sebagaimana diatur dalam Pasal 26 sampai Pasal 29 UU Administrasi Pemerintahan. Di sisi lain, untuk kepastian hukum, perlu juga diperhatikan persyaratan dan pemenuhan substansi dari suatu keadaan untuk menggunakan diskresi, terutama mengingat implikasi hukum dari diskresi apabila penggunaannya tidak memenuhi ketentuan hukum sehingga akibat dari keputusan pejabat publik untuk menggunakan diskresi tidak mengakibatkan jeratan hukum.

Sekalipun diskresi adalah hak yang diberikan kepada pejabat publik, tetapi tidak boleh digunakan secara berlebihan tanpa melakukan dengan penuh 
keyakinan persyaratan dari setiap keadaan yang membolehkan penggunaan diskresi. Hal tersebut guna mencegah terjadinya kesewenang-wenangan dan penyalahgunaan kewenangan oleh pejabat publik, serta mencegah terjadinya justifikasi diskresi sebagai tindak pidana berupa penyalahgunaan kewenangan yang mengarah pada tindak pidana korupsi. ${ }^{25}$

\section{Penutup}

Permasalahan mengenai diskresi hingga kini masih belum tuntas, terutama dalam kaitannya dengan penyalahgunaan wewenang yang dilakukan oleh pejabat publik, sehingga menimbulkan perdebatan di kalangan ahli hukum pidana, praktisi, maupun akademisi hukum pada umumnya. Seiring dengan sifat melawan hukum (wederrechtelijk) sebagai pembatas kewenangan pejabat publik dalam melakukan kebijakan (diskresi) tanpa bergantung pada peraturan perundangan, diskresi dapat dianggap sebagai penyalahgunaan kewenangan jika mengingkari Undang-Undang Nomor 30 Tahun 2014 tentang Administrasi Pemerintahan, sehingga tindakan pejabat publik tidak berujung pada perbuatan yang koruptif.

Pejabat publik dalam memutuskan diskresi senantiasa berpedoman perundang-undangan yang berlaku serta kemanfaatan yang dirasakan masyarakat luas, sehingga penyelenggaraan Negara dapat sesuai dengan Pasal 3 UndangUndang Nomor 28 Tahun 1999 tentang Penyelenggaraan Negara yang Bersih Dan Bebas Dari Korupsi, Kolusi, dan Nepotisme, sekalipun diskresi adalah hak yang diberikan kepada pejabat publik, namun tidak boleh digunakan secara berlebihan tanpa melakukannya dengan penuh keyakinan persyaratan dari setiap keadaan yang membolehkan penggunaan diskresi tersebut.

\section{Daftar Pustaka}

\section{Buku}

Minarno, Nur Basuki, Penyalahgunaan Wewenang dan Tindak Pidana Korupsi dalam Pengelolaan Keuangan Daerah, Cetakan ke-2, Penerbit Laksbang Mediatama, Palangkaraya, 2009.

Ridwan, Diskresi \& Tanggung Jawab Pemerintah, Penerbit FH UII Press, Yogyakarta, 2014. 
Supeno, Hadi, Korupsi di Daerah: Kesaksian, Pengalaman, dan Pengakuan, Penerbit Total Media Yogyakarta, 2009.

\section{Jurnal}

Afdiningsih, Fuji Lara Sakti, H.A. Sihabudin, dan Puspita Asri Praceka, "Framing Pemberitaan Diskresi Ahok untuk Reklamasi Jakarta pada Majalah Tempo, Kajian Jurnalisme, Vol. 1 No. 1, 2017.

Irawan, Benny, “Diskresi sebagai Tindak Pidana Korupsi: Kajian Kriminologi dan Hukum terhadap Fenomena Pejabat Otoritas", Mimbar, Vol. 27 No. 2, Desember 2011.

Jaya, Ikmal, "Implementasi Kebijakan Diskresi pada Sistem Pelayanan Publik di Kota Tegal", Jurnal Pembaharuan Hukum Vol. 1 No. 2, Mei-Agustus 2014.

Mustamu, Julista, "Diskresi dan Tanggungjawab Administrasi Pemerintahan", Jurnal Sasi, Vol. 17 No. 2, April-Juni 2011.

Nurudin, Agus, "Diskresi Yudisial: Antara Keadilan dan Pencitraan", Jurnal Masalah-Masalah Hukum, Jilid 45 No.1 Januari 2016.

Prakoso, Abintoro, "Vage Normen sebagai Sumber Hukum Diskresi yang belum Diterapkan oleh Polisi Penyidik Anak", Jurnal Hukum, No. 2 Vol. 17 April 2010.

Ridwan, "Diskresi (Freies Ermessen) oleh Pejabat publik: Rambu Hukum, Alat Ukur Keabsahan, dan Kecermatan dalam Penggunaanya", Fakultas Hukum Universitas Sriwijaya, Vol. 16 No. 3, Desember 2009.

Sumeleh, Elisa J.B., "Implementasi Kewenangan Diskresi dalam Perspektif Asasasas Umum Pemerintahan yang Baik (AUPB) Berdasarkan UndangUndang No. 30 Tahun 2014 Tentang Administrasi Pemerintahan", Lex Administratum, Vol. 5 No. 9, November 2017.

Susilo, Agus Budi, "Makna dan Kriteria Diskresi Keputusan dan/atau Tindakan Pejabat Publik dalam Mewujudkan Tata Pemerintahan yang Baik", Jurnal Hukum dan Peradilan, Vol. 4 No. 1, Maret 2015.

\section{Hasil Penelitian/Tugas Ahir}

Hutuley, In, Alwi, dan Hasniati, “Diskresi dalam Implementasi Kebijakan Alokasi Dana Desa di Kecamatan Leihitu Kabupaten Maluku Tengah", STIA Abdul Azis Kataloka Ambon, 2013, hlm. 1-13

Wijaya, Ika Hadi, Istislam, dan Moh. Fadli, "Keabsahan Diskresi dalam Penyelesaian Sisa Pekerjaan yang Bukan Disebabkan Force Majeure", Program Magister Ilmu Hukum, Universitas Brawijaya, 2015, hlm.1-26

\section{Makalah/Pidato}

Indarti, Erlyn, "Penegakan Hukum dan Diskresi: Suatu Telaah Paradigmatik", Makalah pada Training Rule of Law Sebagai Basis Penegakan Hukum dan Keadilan, Jakarta, Oktober-November 2015. 


\section{Putusan Mahkamah Agung Republik Indonesia}

Putusan MA No. 1537 K/Pid/2003 tanggal 27 September 2007 dalam perkara a.n. Terdakwa: Drs. H. Sudaryanto.

Putusan MA No. 2349 K/PID.SUS/2012 tanggal 21 Agustus 2013 dalam perkara a.n. Yossep M. Ridwan bin M. Asy'ari selaku konsultan pengawas.

Putusan MA No. 1144 K/Pid/2006 tanggal 13 September 2007 dalam perkara a.n. Edward Cornellis William Neloe selaku Direktur Utama PT. Bank Mandiri (Persero) Tbk.

Putusan MA No. 674 K/PID/2005 tanggal 15 September 2005 dalam perkara a.n. Terdakwa Muaz Munziri, S.E.,MSM.

Putusan MA No. 2547 K/PID.SUS/2011 tanggal 07 Maret 2012 pada perkara Walikota Bekasi Mochtar Mohamad.

Putusan MA tanggal 18 Desember 1984 Nomor: $892 \mathrm{~K} / \mathrm{Pid} / 1993$ dan dalam Putusan MA No. 103 K/PID.SUS/2013 tanggal 30 September 2013 a.n. Ir. Ananto Sukmono.

\section{Peraturan Perundang-undangan}

Undang-Undang Nomor 28 Tahun 1999 tentang Penyelenggaraan Negara Yang Bersih Dan Bebas Dari Korupsi, Kolusi, dan Nepotisme.

Undang-Undang Nomor 31 Tahun 1999 sebagaimana diubah dan ditambahkan dengan Undang-Undang Nomor 20 Tahun 2001 tentang Pemberantasan Tindak Pidana Korupsi.

Undang-Undang Nomor 7 Tahun 2006 tentang Pengesahan United Nations Convention Against Corruption (UNCAC) atau Konvensi Perserikatan Bangsa-Bangsa Anti Korupsi

Undang-Undang Nomor 48 Tahun 2009 tentang Ketentuan-Ketentuan Pokok Kekuasaan Kehakiman.

Undang-Undang Republik Indonesia No.30 Tahun 2014 Tentang Administrasi Pemerintahan 